\title{
Health status of a sample of Beninese seafarers examined on the occasion of medical fitness
}

\section{for work at sea}

\author{
Paul Ahoumènou Ayelo ${ }^{1}$, Brice Lodde ${ }^{2}$
}

${ }^{1}$ Department of Occupational Medicine, Faculty of Health Sciences of Cotonou, University of Abomey-Calavi, Benin, France ${ }^{2}$ Department of Occupational Medicine, University of Western Brittany, Brest, France

\begin{abstract}
Background: In view of the considerable risks involved in maritime work, the medical fitness of seafarers is of paramount importance. A study carried out in May 2018 in Benin made it possible to describe the health profile of seafarers who received a medical examination before boarding and to identify the diseases likely to hinder their medical aptitude for this profession.

Materials and methods: This is a retrospective cross-sectional study that was based on 125 medical files registered from 2013 to 2017 and selected on the basis of the criteria of completeness, readability and non-overload of the entries.

Results: The results showed that more than half (63.2\%) of the seafarers in our series are over 40 years old. The prevalence of high blood pressure was $28.4 \%$ in the seafarer population. Obesity was detected in $21.5 \%$ of subjects. Of the moderate cases of hearing loss found, 4 out of 5 worked at the machine station. The unrestricted fitness level was $86.4 \%$. One $(0.8 \%)$ case of physical restriction and $12.8 \%$ of cases of mandatory wearing of medical glasses at work were reported. The "healthy worker effect" may underestimate the risk of marine activity to the health of seafarers when referring to the general population.

Conclusions: The study provides opportunities to improve the seafarers' health situation in accordance with international provisions such as the Maritime Labour Convention, 2006 (MLC, 2006) ratified by Benin in June 2011.
\end{abstract}

(Int Marit Health 2019; 70, 4: 226-231)

Key words: work, sea, fitness, disease

\section{INTRODUCTION}

The sea is dangerous, Thierry Sauvage said in an article published in 2014 [1]. Dominique Jégaden specified that the contact between the human being and the maritime environment, whether for professional reasons, proximity or leisure, generates all kinds of pathogenic and accidentogenic situations [2]. These two statements raise the whole issue of the occupation of seafarers.

In this context of high risks, the international community has taken all appropriate measures to reduce the damage through the standards of the International Labour Organisation (ILO) and the International Maritime Organisation (IMO). These standards are relayed at national level after ratification.
Shipowners and seafarers therefore are subject to international requirements for occupational safety and health. Among these requirements, the medical fitness for the function of seafarers is of paramount importance.

Benin ratified the Maritime Labour Convention, 2006 (MLC, 2006) on June 13, 2011. Since then, its approach to medical surveillance of seafarers' health has entered a process of continuous improvement that it is important to assess regularly. In the present study, we decided to assess this Beninese medical surveillance focused on a sample of Beninese seafarers serving on a ship under Beninese flag in Benin. The main objectives were to describe the health status of these seafarers and to 
identify the diseases likely to hinder their medical fitness for this profession.

\section{MATERIALS AND METHODS}

\section{FRAMEWORK AND TYPE OF STUDY}

The study was conducted at the Unit of Research and Teaching in Occupational Health and Environment (URESTE) in charge of medical examinations of seafarers in Benin.

This is a descriptive and retrospective cross-sectional study that relies on the medical data of seafarers from all socio-professional categories examined on the occasion of a visit in order to determine their medical fitness for work at sea (preemployment, periodical or return to work) from 2013 to 2017.

\section{SAMPLING AND INCLUSION CRITERIA}

This study used a non-probability sampling method.

All medical records established in the URESTE study period were systematically tabulated.

At the end of the recounts, the files meeting the following criteria are included in the study:

- records from 2013 to 2017;

- completeness of the filling of the file;

- readability of the file;

- no overloading of entries on the file.

Thus, files that do not meet the above requirements are systematically excluded from the study.

\section{COLLECTION OF DATA}

In addition to the tabulation of all medical records from 2013 to 2017, data collection also included the review of national and international standards for seafarers' occupational safety and health at sea.

\section{VARIABLES STUDIED}

- Age and sex of seafarers

- Types of ship

- Health profile:

- Medical and surgical history

- Declared lifestyle (tobacco, alcohol and drugs)

- Health situation on board

- Results of medical examinations (visual acuity, auditory acuity, clinical and paraclinical data)

- Diseases screened at risk of incapacity

- Fitness rate in relation to work-position (bridge, machine, catering and others) and degree of fitness (unrestricted or restricted)

\section{DATA PROCESSING AND ANALYSIS}

The data was processed and analysed using the EPI INFO ${ }^{\circledR}$ software. A simple descriptive analysis was done with some comparisons between some exposure and outcome variables.

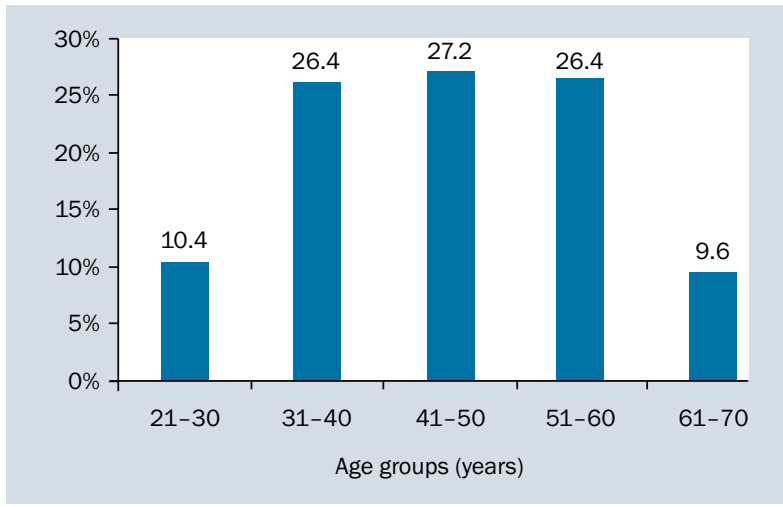

Figure 1. Distribution of seafarers by age group

The $p$-value significance threshold for the data was set at $5 \%$.

\section{ETHICAL CONSIDERATIONS}

Medical data of seafarers are kept confidential against any access by persons outside the service of URESTE. Although they are not aware of exploitation for scientific research purposes such as this, their data are not subject to illegal manipulation, contrary to research ethics and the international code of ethics for occupational health professionals.

\section{RESULTS}

\section{AGE AND SEX OF SEAFARERS}

The average age of seafarers was $45 \pm 11$ years old. The youngest is 21 years old, the oldest being 66 years old (Fig. 1). The subjects aged 31 to 60 are the most numerous $(80 \%)$ in the maritime profession. They are all male.

\section{MEDICO-SURGICAL HISTORY AND LIFESTYLE}

The most commonly reported disease is high blood pressure for which they are on treatment (15.1\%) in addition to eye troubles $(6.3 \%)$, haemorrhoids $(2.4 \%)$ and gastritis (1.6\%). Those who reported drinking alcohol regularly accounted for $5.6 \%$ of the workforce.

\section{CLINICAL DATA}

Visual acuity with and without corrective lenses and colour perception

In Benin as in many other French-speaking countries the measurement of visual acuity is done by using Monoyer scale.

By reading letters at a distance of 5 metres the visual acuity is calculated from 0 to $10 / 10$.

Even if it is recommended by STCW Code Table A-1/9, the Snellens test is not used in Benin. The limit of 
Table 1. Distribution of seafarers according to their visual acuity on Monoyer scale

\begin{tabular}{llllll}
\hline Visual acuity (to ten) & \multicolumn{2}{l}{ Without correction } & & \multicolumn{2}{l}{ With corrective lenses } \\
\cline { 2 - 3 } \cline { 5 - 6 } & Number & $\%$ & 3.4 & & Number \\
\hline$<6$ & 4 & 10.2 & 0 & 0 \\
$6-8$ & 12 & 86.4 & 2 & 28.6 \\
$>8$ & 102 & 100 & 5 & 71.4 \\
Total & 118 & & 7 & 100
\end{tabular}

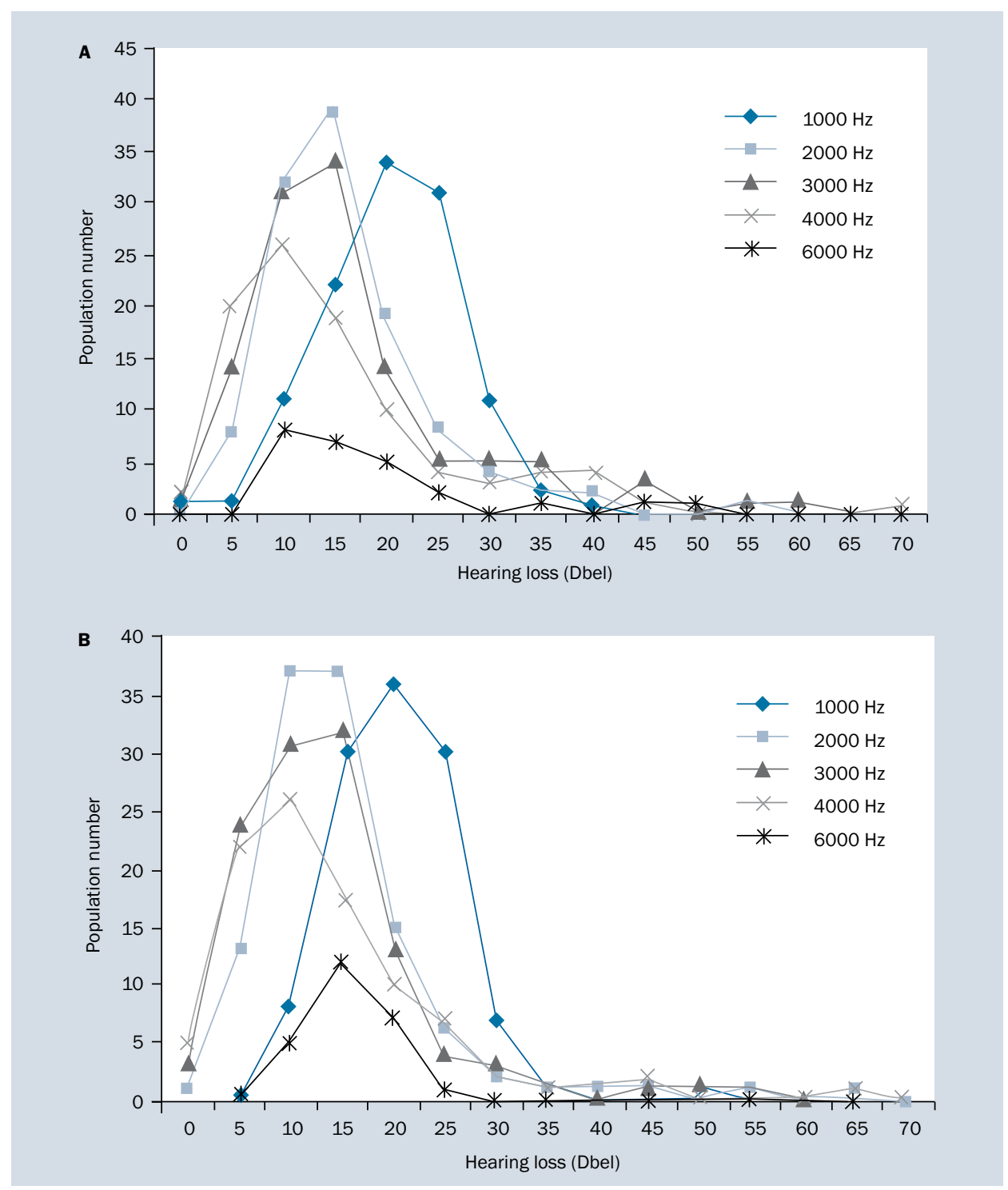

Figure 2. Distribution of seafarers according to their left (shown on the panel A) and right (shown on the panel B) auditory acuity

visual acuity (eventually with corrective lenses) for an onboard work place (assessed by Monoyer scale) is 5/10 (Table 1).

Some cases of low visual acuity have been found in seafarers.

No colour perception disorder was detected.

\section{Hearing acuity}

The Figure 2 above shows that most of the seafarers examined had good hearing acuity on all frequencies studied. However, 3 individuals had moderate hearing losses of 30 to $35 \mathrm{~dB}(\mathrm{~A})$ on the 2000,3000 and $4000 \mathrm{~Hz}$ frequencies. 
Table 2. Distribution of seafarers according to their right hearing at $4000 \mathrm{~Hz}$ and the workstation

\begin{tabular}{|c|c|c|c|c|}
\hline \multirow[t]{2}{*}{ Workstation } & \multicolumn{2}{|c|}{ Right hearing at $4000 \mathrm{~Hz}$ in dB (A) } & \multirow[t]{2}{*}{ Total } & \multirow[t]{2}{*}{$\mathbf{P}$} \\
\hline & $\leq 30 \mathrm{~dB}$ & $>30 \mathrm{~dB}$ & & \\
\hline $\begin{array}{l}\text { Deck [n] } \\
\text { Line } \\
\text { Column }\end{array}$ & $\begin{array}{l}43 \\
97.7 \% \\
51.8 \%\end{array}$ & $\begin{array}{l}1 \\
2.3 \% \\
20.0 \%\end{array}$ & $\begin{array}{l}44 \\
100.0 \% \\
50.0 \%\end{array}$ & 0.0928 \\
\hline $\begin{array}{l}\text { Machine [n] } \\
\text { Line } \\
\text { Column }\end{array}$ & $\begin{array}{l}27 \\
87.1 \% \\
32.5 \%\end{array}$ & $\begin{array}{l}4 \\
12.9 \% \\
80.0 \%\end{array}$ & $\begin{array}{l}31 \\
100.0 \% \\
35.2 \%\end{array}$ & 0.0928 \\
\hline $\begin{array}{l}\text { Restoration [n] } \\
\text { Line } \\
\text { Column }\end{array}$ & $\begin{array}{l}13 \\
100.0 \% \\
15.7 \%\end{array}$ & $\begin{array}{l}0 \\
0.0 \% \\
0.0 \%\end{array}$ & $\begin{array}{l}13 \\
100.0 \% \\
14.8 \%\end{array}$ & 0.0928 \\
\hline $\begin{array}{l}\text { Total }[n] \\
\text { Line } \\
\text { Column }\end{array}$ & $\begin{array}{l}83 \\
94.3 \% \\
100.0 \%\end{array}$ & $\begin{array}{l}5 \\
5.7 \% \\
100.0 \%\end{array}$ & $\begin{array}{l}88 \\
100.0 \% \\
100.0 \%\end{array}$ & 0.0928 \\
\hline
\end{tabular}

Table 3. Distribution of seafarers according to their left hearing and the workstation at $4000 \mathrm{~Hz}$

\begin{tabular}{|c|c|c|c|c|}
\hline \multirow[t]{2}{*}{ Workstation } & \multicolumn{2}{|c|}{ Left hearing at $4000 \mathrm{~Hz}$ in $\mathrm{dB}(\mathrm{A})$} & \multirow[t]{2}{*}{ Total } & \multirow[t]{2}{*}{$\mathbf{P}$} \\
\hline & $\leq 30 \mathrm{~dB}$ & $>30 \mathrm{~dB}$ & & \\
\hline $\begin{array}{l}\text { Deck [n] } \\
\text { Line } \\
\text { Column }\end{array}$ & $\begin{array}{l}42 \\
95.5 \% \\
53.2 \%\end{array}$ & $\begin{array}{l}2 \\
4.5 \% \\
22.2 \%\end{array}$ & $\begin{array}{l}44 \\
100.0 \% \\
50.0 \%\end{array}$ & 0.0167 \\
\hline $\begin{array}{l}\text { Machine [n] } \\
\text { Line } \\
\text { Column }\end{array}$ & $\begin{array}{l}24 \\
77.4 \% \\
30.4 \%\end{array}$ & $\begin{array}{l}7 \\
22.6 \% \\
77.8 \%\end{array}$ & $\begin{array}{l}31 \\
100.0 \% \\
35.2 \%\end{array}$ & 0.0167 \\
\hline $\begin{array}{l}\text { Restoration [n] } \\
\text { Line } \\
\text { Column }\end{array}$ & $\begin{array}{l}13 \\
100.0 \% \\
16.5 \%\end{array}$ & $\begin{array}{l}0 \\
0.0 \% \\
0.0 \%\end{array}$ & $\begin{array}{l}13 \\
100.0 \% \\
14.8 \%\end{array}$ & 0.0167 \\
\hline $\begin{array}{l}\text { Total [n] } \\
\text { Line } \\
\text { Column }\end{array}$ & $\begin{array}{l}79 \\
89.8 \% \\
100.0 \%\end{array}$ & $\begin{array}{l}9 \\
10.2 \% \\
100.0 \%\end{array}$ & $\begin{array}{l}88 \\
100.0 \% \\
100.0 \%\end{array}$ & 0.0167 \\
\hline
\end{tabular}

Subjects who did not perceive sounds above $30 \mathrm{~dB}(\mathrm{~A})$ (as shown in Table 2) at the frequency of $4000 \mathrm{~Hz}$ at the right ear are mostly (80\%) at the machine station.

Subjects who did not perceive sound above $30 \mathrm{~dB}(\mathrm{~A})$ (as shown in Table 3) at the frequency of $4000 \mathrm{~Hz}$ at the left ear are mostly (77.8\%) at the machine station.

\section{Body mass index}

Normal-weight subjects are those with the body mass index (BMI) less than 25. Overweight subjects are those with a BMI of 25 to 30 . Obese subjects have higher BMI than 30 (Fig. 3).

\section{Blood pressure}

High blood pressure has been detected in almost onethird of seafarers in the past five years (Table 4).

\section{Physical examination}

The physical examination data were poor and consisted of 2 cases of discrete opacities of the lens (early cataract), 3 cases of abdominal pain on palpation (probable peptic

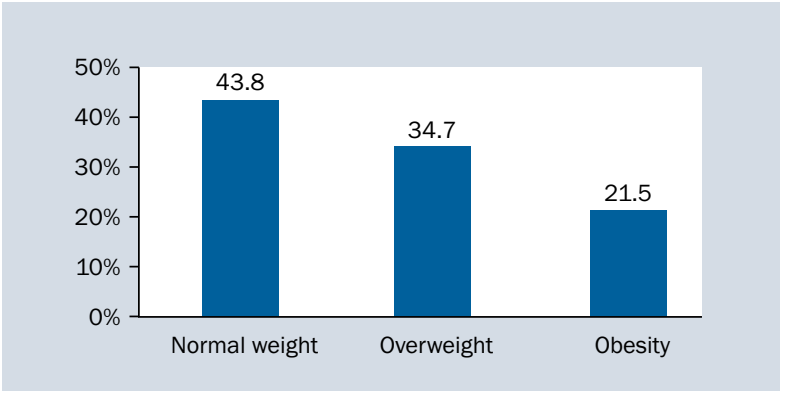

Figure 3. Distribution of seafarers according to their body mass index

Table 4. Distribution of seafarers by blood pressure (BP)

\begin{tabular}{llll}
$\begin{array}{llll}\text { Systolic } \\
\text { BP }\end{array}$ & \multicolumn{2}{l}{ Diastolic BP } & Total \\
\cline { 2 - 3 } & $<\mathbf{9 0}$ & $\mathbf{2 9 0}$ & \\
\hline$<140$ & $72(62.07 \%)$ & $4(3.45 \%)$ & $76(65.52 \%)$ \\
$\geq 140$ & $7(6.03 \%)$ & $33(28.45 \%)$ & $40(34.48 \%)$ \\
Total & $79(68.1 \%)$ & $37(31.9 \%)$ & $116(100 \%)$
\end{tabular}




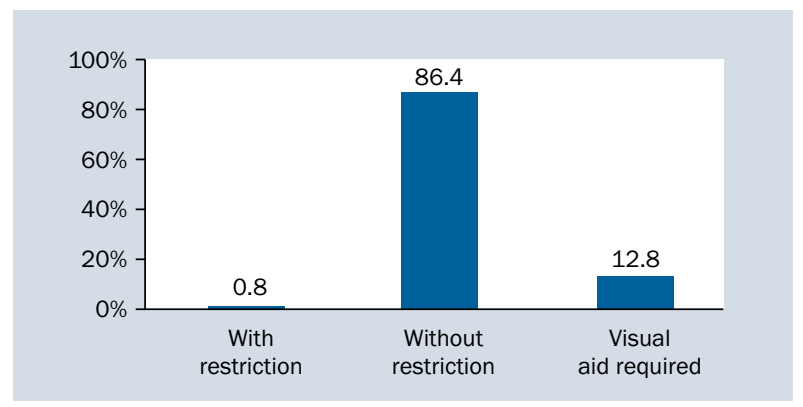

Figure 4. Distribution of seafarers by medical fitness notice

gastritis), 2 cases of varicose veins of the lower limbs, and 1 case of tympanic perforation without inflammation or suppuration. The rest of the physical examination was unspecific about all 125 medical visits.

\section{URINE TESTS}

The search for glycosuria, proteinuria and haematuria using urinary strips was negative for all 125 seafarers.

\section{NOTICE OF MEDICAL FITNESS}

Most of the fitness notices were given without restriction (86.4\%). $12.8 \%$ of the medical examinations led to the following conclusion: visual correction is needed at the on-board work-place (wearing corrective lenses). In $0.8 \%$ of the cases, fitness with restriction was concluded (Fig. 4).

\section{DISCUSSION}

\section{LIMITATIONS AND BIASES OF THE STUDY}

The study was conducted on a sample of 125 medical records of seafarers received from 2013 to 2017, over a period of 5 years. This is not a cohort study. Hence, it is not possible to conclude regarding any change in individual health even if the seafarers had the possibility to be seen at least 2 times in this relatively long period.

The collected anamnesis for each individual was based on a proper declaration. There was no medical record for prior health trouble for these candidates for first employment at sea or seafarers yet. Moreover some of the candidates were looking for work. So we could cast doubt on their reliability if these people know that their medical histories are supposed to impair their fitness for work at sea. These anamneses are part of punctual examinations such as taking blood pressure that are not constituting a "long life" medical file.

Nevertheless, seafarers who come for medical checkups prior to boarding are generally those who are supposed to be in good health. As Gollac said, "a worker occupies a position only if his health permits" [3]. Then we can probably face a self-selection bias in our study [4].

\section{HEALTH STATUS OF THIS SAMPLE OF BENINESE SEAFARERS}

\section{Age, high blood pressure and obesity}

Our seafaring population is made up of aging subjects who are therefore more exposed to age-related diseases, particularly cardiovascular diseases. The influence of age in the physical fitness of the workers is well established.

High blood pressure was reported by $15.1 \%$ of seafarers and they were under treatment. Other cases were found at the medical visits, bringing the prevalence of high blood pressure in the seafarers' population to $28.4 \%$. This prevalence appears to be slightly higher than that found in the general population in Benin, which was $27.9 \%$ in 2008 [5]. Further studies are needed to investigate if the maritime work could be considered here as an inductor of high blood pressure. In fact, on-board noise exposure or stress could represent some risk factors that could explain this prevalence.

Maritime work would also be taken into account to explain the prevalence of obesity at $21.5 \%$ in our series. This is almost the same situation in Denmark in 2007 where $25 \%$ of seafarers were obese with a $\mathrm{BMI}>30$ compared to $12 \%$ of the adult male Danish population [6].

The maritime work-obesity-high blood pressure relationship is simple to understand and resides essentially in the sedentary nature of the maritime activity. This is a closed, often cramped work environment where physical exercise and sport opportunities in most vessels are virtually non-existent.

\section{Visual and auditory state}

All of the seafarers examined met the STCW criteria for visual acuity and colour vision. However, vision problems are to be considered for $12.8 \%$ of seafarers (Table 1 ) who were required to wear medical glasses. The main was ametropia. The fact that visual acuity and colour vision of this sample of seafarers fit with the standards of watchkeeping are singular but could be explain by a self-selection bias.

Auditory acuity testing has been normal for most seafarers. Of the moderate cases of hearing loss recorded, 4 out of 5 are revealed as to work at the machine station. It is known to researchers in maritime medicine that the machine station in a ship is an important source of noise exposure. The international regulations are firm on this issue, particularly with regard to the assessment of risk during medical examinations for seafarers and the application of hearing protection measures.

\section{MEDICAL FITNESS OF SEAFARERS}

It must be admitted that the act of issuing medical fitness decisions in Benin is essentially based on the screening for disabilities that are incompatible with the maritime activity or that may be aggravated by it. Medical examina- 
tions are carried out according to ILO/IMO guidelines [7]. No definitive unfitness decision has been formulated in our series. It should be noted that in general, notifications of unfitness are rare because Zevallos in the Netherlands, having studied a much larger population of seafarers (7617) in 2012 , found $0.6 \%$ of unfitness and $4 \%$ of restricted fitness cases [8]. This small difference in results could be explained by the fact that seafarers, in the socio-economic context in Benin, do not present themselves for the medical examinations for fitness until they feel well (self-selection bias) and because of the disproportionate size of the sample.

\section{DISEASES THAT MAY HINDER THE FITNESS OF SEAFARERS}

We found that the following diseases are likely to hinder the medical fitness of seafarers in the medium and long term.

In the medium term, these are cardiovascular diseases (hypertension, coronary insufficiency) and metabolic disorders (diabetes, gout, metabolic acidosis). Contributing factors would be the personal history of hypertension, the age of individuals, obesity related to physical inactivity and diets too fat and salty on board ships. These cardiovascular risks, which account for about $80 \%$ of marine medical evacuations [9], are present even though they are obscured by the self-selection bias under our methodological approach [10].

In the long term, chronic visual disturbances should be feared if workplace lighting is inadequate, hearing impairment and occupational deafness at the machine station level when prevention measures are not rigorously applied.

In addition, the problems of venous insufficiency with types of varices of the lower limbs and haemorrhoids are to be taken into consideration because of the favourable conditions such as the sedentariness and the absence of regular physical and sport exercises on board the ships.

\section{CONCLUSIONS}

The results of this study present a sample view of fitness for work at sea of seafarers regularly embarked in Benin. By regarding the health status of this population, we identified surveillance elements and ways to control conditions that may hinder the seafarers' medical fitness for work at sea.
Since 2011, Beninese seafarers' doctors declare fit or unfit seafarers in accordance with Beninese regulations based on ILO/IMO guidelines on medical examinations of seafarers, which are developed based on the MLC 2006 principles and the STCW requirements and national specific regulations. This application suggests that the health status of this population is now better assessed. Nevertheless, when taking a look at the low percentage of health troubles leading to unfitness (that could be sometimes related to work), further investigations are needed to know if occupational diseases and work-related accidents in Beninese seafarers are correctly prevented by application of appropriate measures or if affected seafarers quit their work activity (due to these kind of health troubles) without medical follow-up by seafarers doctors.

\section{REFERENCES}

1. Sauvage T. "La mer est dangereuse, n'en rajoutez pas". Travail et sécurité. 2014; 756: 10-12.

2. Jégaden $D$, Dewitte JD. De l'hygiène navale à la médecine du travail maritime. Arch Mal Prof Env. 2007; 68(3): 219-222, doi: 10.1016/ s1775-8785(07)88933-8.

3. Gollac M, Volkoff S. La santé au travail et ses masques. Actes de la recherche en sciences sociales. 2006; 163(4): 17.

4. Crasset 0. "On se fait mal un peu tous les jours ", l'effet travailleur sain chez les maréchaux-ferrants. Travail et emploi. 2013(136): 5-20, doi: 10.4000/travailemploi.6109.

5. Houinato DS, Gbary AR, Houehanou YC, et al. Prevalence of hypertension and associated risk factors in Benin. Rev Epidemiol Sante Publique. 2012; 60(2): 95-102, doi: 10.1016/j.respe.2011.09.010, indexed in Pubmed: 22436411.

6. Hjarnoe L, Leppin A. A risky occupation? (Un)healthy lifestyle behaviors among Danish seafarers. Health Promot Int. 2014; 29(4): 720729, doi: 10.1093/heapro/dat024, indexed in Pubmed: 23630132.

7. OIT-OMI. Directives relatives aux examens médicaux des gens de mer. Programme des activités sectorielles. ILO/IMO/JMS/2011/12. ISBN: 978-92-2-225559-7, Genève, 2011.

8. Zevallos J, Hulshof CT, Mutsaerts T, et al. Outcomes of seafarer work fitness qualifications in the Netherlands. Occup Med (Lond). 2014; 64(4): 267-270, doi: 10.1093/occmed/kqu020, indexed in Pubmed: 24604102.

9. Jégaden D, Dewitte JD, Loddé B. L'aptitude à la navigation maritime: une véritable évaluation des risques de maladie. Arch Mal Prof Env. 2005; 66(4): 318-325, doi: 10.1016/s1775-8785(05)79100-1.

10. Oldenburg M. Risk of cardiovascular diseases in seafarers. Int Marit Health. 2014; 65(2): 53-57, doi: 10.5603/IMH.2014.0012, indexed in Pubmed: 25231325. 